\title{
JOSÉ SCARAMELLI E O ESBOÇO DE UMA ESCOLA NOVA "BRASILEIRA"
}

\author{
Débora Alfaro São Martinho da Silva ${ }^{1}$ \\ Alessandra Arce ${ }^{2}$ \\ Universidade Federal de São Carlos (UFSCar)
}

\section{RESUMO}

Este artigo busca compreender como as ideias pedagógicas de autores representantes do Movimento Internacional da Escola Nova adentraram no Brasil na Primeira República, sendo apropriadas, interpretadas e adaptadas à realidade escolar da época por intelectuaiseducadores como José Scaramelli, situado no âmbito da informação-ação, difundem e operacionalizam os sistemas de pensamento de teóricos precursores deste movimento, no espaço dos cursos de formação de professores e de instrução aos alunos de escolas elementares; chegando, mesmo, a propor um esboço de uma Escola Nova com características brasileiras, que pudesse enfrentar e superar os impasses enfrentados pela instrução pública do período. Com base em suas obras didáticas, procura-se responder $o$ $q u \hat{e}$ este intelectual-educador compreendia por Escola Nova e o quêe, segundo esta orientação, propunha para a educação da infância brasileira. Como guias metodológicos foram adotadas as categorias indicadas para a realização de um trabalho dentro de uma perspectiva histórico-crítica em História da Educação: caráter concreto do conhecimento histórico-educacional, a perspectiva de longa duração, o olhar analítico-sintético no trato com as fontes, a articulação do singular e do universal e a atualidade da pesquisa histórica. Palavras-chave: História da educação brasileira; História das ideias pedagógicas; Escola Nova; Intelectuais da educação brasileira; José Scaramelli.

\section{SCARAMELLI AND THE OUTLINE OF A "BRAZILIAN" NEW SCHOOL}

\begin{abstract}
This article aims to understand how the pedagogical ideas of authors which are representatives of New School International Movement had entered the Brazilian First Republic period, which were appropriated, interpreted and adapted to the school reality at that time by educators as Jose Scaramelli who is located in the information-action context, diffuse and operationalize educational thought systems from scholars precursors of this movement, in the space of education course for teachers and also elementary school; coming up even to propose an outline of a new school with Brazilian characteristics, which could face and overcome the difficulties in favor of public education period. Based on his didactic works, this article aims to answer what this intellectual educator used to understand about new school and what, according to this orientation he proposed to the Brazilian childhood education. As methodological guides, we adopted the categories indicated to de work applications of historic-critic approach in Educational History which are: historic-educational knowledge and its concreteness, long-term perspective, analyticsynthetic look when dealing with sources, singular and universal articulation and the actuality of historical research.
\end{abstract}

Keywords: Brazilian Educational History. History of pedagogical ideas. New School. Intellectuals of Brazilian education. Jose Scaramelli. 


\section{INTRODUÇÃO}

Mediante a trajetória de vida e as interlocuções do intelectual e educador brasileiro, José Scaramelli (1894 - 1955), este artigo busca compreender como as ideias pedagógicas de autores precursores do Movimento Internacional da Escola Nova adentraram no Brasil na Primeira República, sendo apropriadas, interpretadas e adaptadas à realidade escolar da época por intelectuais-educadores como José Scaramelli que, situados, não no palco de atuação dos grandes pilares do pensamento renovador brasileiro - como Anísio Teixeira, Lourenço Filho e Fernando de Azevedo -, mas no âmbito da informação-ação, difundem e operacionalizam os sistemas de pensamento de teóricos, como: Claparède, Decroly, Dewey, dentre outros, no espaço direto dos cursos de formação de professores e das escolas elementares; chegando, mesmo, a propor um esboço para uma Escola Nova Brasileira, que pudesse enfrentar e superar os impasses enfrentados pela instrução pública do período.

Barbosa (2011, p. 136), ao analisar as interpretações de Dewey sobre a arte consumatória por educadores brasileiros, dentre eles, a experiência de José Scaramelli na Reforma Pernambucana, afirma que, "no Brasil, a contribuição mais significativa na propagação da ideia e da prática da arte como instrumento para ajudar a formação do conceito foi a do grupo dos Reformadores da Educação de Pernambuco, durante o Movimento da Escola Nova (1927 - 1935)". Para a análise deste conceito, escolhe a Coleção Escola Nova Brasileira, afirmando que, de todos os livros escritos em relação a este movimento, esta coleção é a que "apresenta as descrições mais claras de lições reais, demonstrando a prática em todas as áreas na sala de aula. [...] Além disso, Scaramelli apresenta algumas abordagens teóricas da educação" (p. 137).

Com base nas apropriações e interpretações destes autores, em suas obras didáticas dirigidas ao magistério e à escola primária, procura-se responder $o$ quê este intelectualeducador compreendia por Escola Nova e $o$ quê, segundo esta orientação, propunha para a educação da infância brasileira.

Por História das Ideias Pedagógicas se entende as ideias educacionais,

não em si mesmas, mas na forma como se encarnam no movimento real da educação, orientando e, mais do que isso, constituindo a própria substância da prática educativa. Com efeito, a palavra 'pedagogia' e mais particularmente, o adjetivo 'pedagógico' têm marcadamente ressonância metodológica denotando o modo de operar, de realizar o ato educativo (SAVIANI, 2007a, p. 6).

Como guias metodológicos, o estudo adotou as categorias indicadas por Saviani (2007a, 2007b) como essenciais para a realização de um trabalho dentro de uma perspectiva histórico-crítica em História da Educação, constituindo-se em: a) caráter concreto do conhecimento histórico-educacional: ou seja, por meio de ferramentas conceituais, tomar o fenômeno educacional em sua totalidade concreta, procurando formular as relações que explicam determinados aspectos da realidade investigada, para assim, construir sistemas explicativos que demonstrem o quanto o objeto de estudo está expresso na complexidade das relações e determinações presentes na história de sua época; b) perspectiva de longa duração: conforme as orientações metodológicas de Gramsci, Saviani (2007a) destaca a necessidade de se distinguirem os movimentos orgânicos tempo longo dos acontecimentos, relativamente permanente - dos conjunturais - tempos curto e médio, que são ocasionais, imediatos e quase acidentais -, para poder se estabelecer o nexo dialético entre as duas ordens de movimento e de pesquisa, captando o processo global (o tempo longo das estruturas), em sua unidade dinâmica e contraditória. c) olhar 
analítico-sintético no trato com as fontes: que implica o levantamento e o exame atento das fontes e informações disponíveis, "abrangendo as suas diversas modalidades e articulando-as sincrônica e diacronicamente de modo que não deixe escapar as características e o significado do fenômeno investigado" (SAVIANI, 2007b, p. 4); d) articulação do singular e do universal: trata-se do empenho em encontrar a relação entre o local ou nacional com o universal e vice-versa, detectando em que grau o local ou o nacional constituem expressões de tendências que se impõem intencionalmente (SAVIANI, 2007b). Esse movimento nos permitirá olhar o local sem desvinculá-lo de sua totalidade, pois como destaca Vainfas (2002, p. 150), a pesquisa histórica deve buscar "uma passagem do olhar macrossocial para a observação micro-analítica como procedimento metodológico, sem prejuízo da primeira". O historiador deve, portanto, inserir-se no contexto em que o micro e o macro se entrelaçam, pois, "o quotidiano só tem valor histórico e científico no seio de uma análise dos sistemas históricos, que contribuem para explicar o seu funcionamento" (LE GOFF, 1994, p. 93); e) atualidade da pesquisa histórica: trata-se da consciência e percepção de que o presente se enraíza no passado e se projeta no futuro. Desse modo, não há a possibilidade de se compreender o presente sem se apreenderem suas raízes. Isso implica o estudo de sua gênese.

\section{Uma trajetória em prol da cruzada pela educação}

Lembremo-nos de que não se julga um indivíduo, como um povo, fora das condições do tempo e do meio em que viveu. Cotejá-lo com os povos de hoje, sem atender a essas circunstâncias, é errar redondamente, é agir como criança (TOLEDO, 1918, p. 32).

Em 10 de abril de 1894, nasce na cidade de Serra Negra, São Paulo, José Scaramelli. Neste mesmo ano, inaugura-se na capital do Estado o prédio da Escola Normal de São Paulo, que viria sediar, além do curso normal, a Escola-Modelo Preliminar Antonio Caetano de Campos, a Escola-Modelo Complementar e o Jardim de Infância. Versão condensada do sistema de ensino que se tencionava instituir em São Paulo, esta instituição se constituiria, nos primeiros decênios da República, em padrão de excelência e respeitabilidade, adquirindo grande relevância na vida intelectual e cultural da província, em virtude de suas produções teóricas e iniciativas práticas, recorrentemente atualizadas com vistas à organização e formação de professores para o magistério primário. Como paradigma para a formação do escol do magistério, nela se formou e atuou "parte dos intelectuais de diferentes épocas, responsáveis pela elaboração de teses sobre a realidade social, educacional e cultural brasileira"; vanguardas que se projetam em todo o território nacional, não apenas no âmbito da educação e da cultura, como também na arena política, propagando seus ideais, organizando serviços, disputando o controle e o destino do ensino público brasileiro e forjando a mentalidade educacional hegemônica em diferentes épocas (MONARCHA, 1999, p. 343). Nesta instituição, José Scaramelli se matrícula em 27 de janeiro de 1914 para frequentar o curso normal masculino noturno e adquire os fundamentos teórico-práticos dos hodiernos processos e métodos de ensino, que influenciariam sua prática pedagógica e suas produções didáticas. Forma-se ao final do ano de 1917, ao lado de Lourenço Filho, seu colega de classe.

Diplomado, deixa seu lugar como funcionário dos Correios e Telégrafos, para iniciar o exercício no magistério na Escola Isolada Masculina Urbana de São Joaquim da Barra, em 1919. No ano seguinte é nomeado para o cargo de diretor do Grupo Escolar de 
Pedreira. Cargo que ocupará, ao longo da década de 1920, ao percorrer inúmeras escolas do interior paulista, como: Grupo Escolar de Orlândia, Faculdade Sampaio Dória (1923 1924), Grupo Escolar de Pereiras (1925) e Grupo Escolar de Ourinhos (1928). Ao final do decênio (1929), é convidado, junto a um grupo de professores paulistas, pelo governo pernambucano, para partir em comissão ao Estado, a fim de auxiliar a implantação da reforma de ensino empreendida por Antonio Carneiro Leão (SÃO PAULO, 1919, 1960; INSTRUÇÃO, 1928; MELO, 1954; SILVA, 2013).

A escolha do pessoal capacitado para implementar a reforma pernambucana devese, em parte, a admiração que o reformador dedica às ações promovidas pelo Estado de São Paulo no âmbito educacional. A manifestação deste sentimento é inscrita em seu livro O Brazil e a educação popular.

A ação fecunda da educação paulista foi hipnótica sobre o meu espírito. E felizes os que, vendo e compreendendo o futuro magnífico que aqui se elabora, sofrem o influxo de São Paulo, porque esses terão um surto novo na sua vida, uma nova diretriz no seu destino. Ou convidam-se educadores de São Paulo para que criem a educação popular brasileira, ou ter-se-á de mandar à América do Norte, à Inglaterra ou à Suíça, os nossos mestres, para estudarem e adaptarem, nos seus Estados, o que de interessante e facilmente aplicável encontrarem no estrangeiro (CARNEIRO LEÃO, 1917, p. 20).

Em virtude da excelência que se tornara o ensino paulista, o empréstimo de professores deste Estado, ou melhor, de técnicos - como costumavam ser chamados - às outras regiões do território nacional para superintenderem ações em diversos níveis de seus sistemas de ensino - como, "implantação e/ou reaparelhamento de escolas normais e escolas-modelo, grupos escolares, escolas reunidas e isoladas; órgãos de direção ensino; reorientação de programas, métodos didáticos e elaboração de legislação específica" (MONARCHA, 2010, p. 246) -, tornou-se, nas primeiras décadas dos novecentos, "rotina administrativa na hierarquia das providências com que os responsáveis pela instrução pública dos outros estados tomam como iniciativas de remodelação escolar" (CARVALHO, 2007, p. 226). Este fenômeno, conhecido por missões de professores paulistas, foi relatado por intelectuais da época, como Carlos da Silveira, em seu artigo Missões de professores paulistas, publicado na Revista do Brasil no ano de 1911; Renato Sêneca Fleury, em texto de mesmo nome, publicado no Diário de São Paulo e transcrito na Revista Educação em 1946 e em Bandeirismo, artigo sem identificação autoral, publicado na Polianteia Comemorativa do Ensino Normal em São Paulo (1946), organizada por um grupo seleto de professores. Este trazia a seguinte apreciação:

No bandeirismo no ensino constitui também uma fase da história paulista e é, sem dúvida alguma, reflexo da escola normal. No centenário estabelecido de ensino, síntese de toda uma brilhante evolução da cultura, forjaram-se as primeiras armas didáticas e dele saíram os primeiros combatentes. Justo e natural, pois virem os governos de outros estados solicitar, como no tempo das bandeiras, o contingente paulista para a cruzada da instrução (ROCCO, 1946, p. 69).

Os jornais da época noticiam, também, o fenômeno, destacando alguns técnicos que se lançaram em missão pelo país e informando a partida de José Scaramelli e dos demais técnicos à Pernambuco. O jornal paulista, a Folha da Manhã, publicava em 25 de janeiro 
de 1929: Professores paulistas vão reformar o ensino em Pernambuco: São Paulo continua a auxiliar a instrução em todo o país.

O ensino paulista irradia-se pelo país, dando provas positivas da eficiência de seus métodos didáticos e da capacidade pedagógica dos seus professores. Raro é o Estado que não possui a sua instrução orientada pelos mestres de São Paulo. No Rio de Janeiro está Fernando de Azevedo, que tendo levado Sud Menucci, para o seu próprio orientador, reformou completamente o ensino do Distrito Federal. O Ceará remodelou o seu aparelhamento educativo sob a direção de Lourenço Filho. Em Sergipe encontra-se, organizando as suas escolas, um diretor de grupo desta capital. O Rio Grande do Norte e a Paraíba enviaram os seus mais competentes professores estudar em nossas escolas para depois implantar nos seus Estados o que de melhor encontraram aqui. Minas fez o mesmo e agora, Pernambuco reclama também a cooperação de São Paulo. A convite do governo pernambucano seguiu para o Recife o professor José Escobar, lente da Escola Normal da Praça, com um fim único de dar uma nova orientação ao ensino do grande Estado do Norte. Por indicação do mesmo professor Escobar, acaba de partir o Sr. Pascoal Montesano Salgado, que vai ser o diretor técnico do ensino profissional em Pernambuco. Não é tudo, porém: a convite do mesmo governo nortista, seguirá ainda o professor José Scaramelli, que regerá na Escola Normal do Recife, a cadeira de didática. É uma boa contribuição que São Paulo envia a Pernambuco, destacando dentre o seu professorado mais competente, três nomes conhecidos, que, providos de largo tirocínio e de capacidade pedagógica muito bem experimentada, poderão dizer ao Leão do Norte, o que é a instrução na terra dos bandeirantes (PROFESSORES, 1929, p. 2).

Em Pernambuco, aos 27 dias do mês de fevereiro do ano de 1929, o jornal $A$ Província divulgava: A reforma da educação em Pernambuco: dentre os estados que estão reformando o seu ensino é Pernambuco o que realiza reforma mais radical, diz o "Diário de S. Paulo":

No momento atual, o Brasil inteiro, de norte a sul, agita-se num belo movimento, que conforta e nos enche de confiança no futuro, em torno dos grandes problemas do ensino. No Rio Grande de Sul, o presidente Getúlio Vargas, conforme noticiamos vai contrair um empréstimo de 30.000 contos, para edificar prédios escolares e reformar todo o aparelhamento da Instrução Pública. Em Minas, o sr. Antonio Carlos já realizou uma reforma do ensino. Com destino ao Espírito Santo, segue o prof. Gomes Cardim, diretor aposentado da Escola Normal da Praça, a fim de realizar uma série de conferências pedagógicas, a convite do governo daquele estado. E, em todos os outros Estados e no Distrito Federal, nota-se o mesmo fervor pela alfabetização das massas populares. Dentre estes, Pernambuco, sem dúvida, é o que realiza reforma mais radical. Nela colaboram vários educadores paulistas. Uns que já se acham no Recife e outros que estão a caminho daquela capital. Embarcou, ontem, em Santos, com esse destino, o professor Scaramelli, que vai reger a cadeira de Didática da Escola Normal de Recife (A REFORMA ..., 1929, 1929, p. 3). 
Dado o valor da cadeira de Didática no texto de Justificativa da reforma pernambucana - "cadeira por excelência preparadora do mestre", que, "numa renovação contínua, experimentando todos os métodos, verificando o êxito dos centros de interesse, dos processos montessorianos, froebelianos, do manualismo na educação, da escola ativa, etc." deveria "formar o professor, com segurança técnica, feita de experiências" (CARNEIRO LEÃO, 1928, p. 17) -, que tornaria a Escola de Aplicação - concebida como Instituto de Pesquisas Pedagógicas, cuja função seria atuar como um verdadeiro laboratório, local de estágio e pesquisa para prática do aluno-mestre (ARAÚJO, 1991) -, em instrumento de importância capital para o estabelecimento do curso profissional normal, prevendo um corpo docente constituído pelo caráter mais adiantado e entusiasta; seu reformador sugere a conveniência de que professor desta disciplina na escola normal fosse também diretor da Escola de Aplicação, pois no primado do método, os meios seriam importantíssimos para a condução das inovações (CARNEIRO LEÃO, 1928). Em virtude da carência de profissionais que atendessem as exigências de qualificação para tais funções, Carneiro Leão admite a necessidade de serem contratados professores de outras localidades, nacionais ou estrangeiros, mas de "notória competência" (ARAÚJO, 1991, p. 119). Para este fim, José Scaramelli é convidado para inaugurar a cadeira de Didática na Escola Normal Oficial de Recife e dirigir simultaneamente a Escola de Aplicação anexa à mesma.

Embora no decênio de 1920, José Scaramelli tenha se debruçado na elaboração e publicação dos primeiros ensaios de uma escola nova com características brasileiras, mediante a produção de livros didáticos sobre temas de Ciências, História do Brasil, Moral e Cívica, ensino da língua materna, cartilhas para alfabetização e da Revista Infantil, dirigidos à formação da infância e juventude; um tratado de Metodologia Geral do Ensino; além de artigos de jornais, é após sua experiência em Pernambuco, que sistematiza, na coleção Escola Nova Brasileira, os princípios norteadores desta orientação, provendo-a do aparato teórico sobre o conhecimento da criança e dos processos de ensinar e aprender e do aparato técnico-prático, constituído por inúmeros exemplos de aulas demonstrativas, que serviriam de guia ao professor no processo de transição da escola tradicional para a escola nova.

No primeiro livro da coleção, Escola Nova Brasileira: esboço de um sistema, José Scaramelli (1931a, p. 89) descreve o desenvolvimento de uma aula-modelo na Escola de Aplicação Oficial de Recife - tomada como "aula belíssima da qual não se esqueceria" -, regida pela professora Maria Luiza Cavalcanti de Albuquerque Maranhão, uma de suas "mais brilhantes colaboradoras", relatando as impressões e memórias desta experiência, quando lhe coubera à honra de dirigi-la e organizá-la segundo os princípios da Escola Nova.

Se me não assaltasse o receio de me acoimarem de modéstia, por que fui nisso mínima parte, com certeza a menos valiosa, - receio terrível que me há refreiado, na vida, constantemente, o anseio de voar - ousaria afirmar que, talvez, se tivesse realizado, naquele casarão secular da Praça 13 de maio, no Recife, o mais sério ensaio de Escola Nova, que se operou até esta data no Brasil. Escolhidas com meticuloso cuidado, para ali foram destacadas as melhores professoras do Recife, cerca de trinta colegas inteligências brilhantíssimas, culturas invulgares, dedicações extraordinárias, - que horariam soberbamente o magistério de qualquer país do mundo. E foi sob o esplendor de tais constelações - verdadeiros sóis coruscantes, - que o humilde subscritor destas linhas viu levantar-se, 
como um lindo sonho de fadas, a mais bela escola experimental que the foi dado a conhecer nesta formosa Terra de Santa Cruz.

Entretanto, não somente de contos de fadas constituiu-se a estadia de José Scaramelli e dos demais técnicos paulistas comissionados em Pernambuco. A introdução dos preceitos escolanovistas incorporados na didática e metodologia da Escola Normal de Recife enfrentou grande oposição e violentos protestos do grupo de professores locais, do círculo católico e dos órgãos da imprensa que se aturdiram com o programa instituído este incluía "a fisiologia dos sapos e das minhocas e a fecundação das ratas e ainda aulas práticas das professorandas na Fazenda Modelo Tijipió" -, chegando a resultar em abaixoassinado enviado ao Diário de Pernambuco e, mesmo, em uma passeata, em que se simulava o enterro de José Escobar pelos acadêmicos (LEMOS FILHO, 1960). Somente quando os itens julgados escabrosos foram retirados do programa da Escola Normal é que se cessaram os protestos. Como relata Lemos Filho (1960, p. 21): "O professor Escobar era o prato do dia [...] além de colocar sua senhora na Escola Normal como mestra de trabalhos femininos, mandou vir o seu colega, professor José Scaramelli". Os jornais oposicionistas da época publicavam em suas páginas versos satíricos dirigidos à metodologia dos professores paulistas. Alguns destes foram encontrados na coleção de literatura "de tostões" de Lemos Filho (1960, p. 213), como os remetido a José Escobar:

Dizem que o programa da Normal

Tem coisas que eu não posso acreditar;

Que tem sapos, minhocas, lagartixas,

E como o rato faz para se casar.

Gosto

Que me enrosco

De pensar só

No que lá em casa vai dizer vovó,

Quando a Ziza contar tudo o que viu

E que assistiu

Lá em Tijipió.

E os referentes à "prosódia" de José Scaramelli:

Diz ele cheio de brio,

Da sua ciência orgulhoso:

- Programa maravilhoso

Eu trouxe de lá do Rio.

Dizendo que não se iguala

A quem prega sem ter lido,

Afirma: "Estou bem munido

Só de livros, duas malas" (Grifos do autor).

Araújo (1991, p. 154) esclarece que as dificuldades que os condutores da Reforma Pernambucana se defrontaram já eram esperadas, tendo, uma série de fatores, contribuído:

a falta de envolvimento/comprometimento dos que integravam o sistema educacional: sua dissociação da realidade Pernambucana; a vinda da equipe responsável pela sua implantação e desenvolvimento, de São Paulo, Estado que apresenta características econômicas e sociais diversas das nossas; o forte clima de hostilidade existente então em Pernambuco refletindo particularmente em importantes setores da imprensa - contra o 
governador Estácio Coimbra, legítimo representante do Velho Regime, às vésperas da eclosão da Revolução de 30, e finalmente, a escassez de recursos financeiros, a despeito da promessa feita pelo governador a Escobar, que fora persuadido a assumir a Diretoria Técnica de Educação porque "[...] as verbas para as escolas seriam elevadas a mais do dobro dos 5\% habituais"(Grifos da autora).

Em meio às adversidades enfrentadas pelos condutores da Reforma pesava, como já atestado, "a maneira como foi conduzida a disciplina de Anatomia e Fisiologia Humanas, criando uma enorme polêmica, chegando até a ameaçar o governo"; pois a introdução de elementos de educação sexual: assunto bastante controvertido para a época, constituiu um verdadeiro impasse, resultando contundentes críticas da imprensa local (ARAÚJO, 1991, p. 154). Além das adversidades engendradas pela reforma do sistema educacional pernambucano, complementa Araújo (1991), contribuiria para a exoneração de Scaramelli, o fator relativo à perda de sustentação política da administração de Estácio Coimbra em virtude das mudanças engendradas pela Revolução de 1930. Numa tentativa de reverter o quadro de insatisfação perante a crise suscitada pelas renovações metodológicas introduzidas pela Reforma, Estácio Coimbra convida-o para "dirigir do alto" a execução da Reforma. Porém, Freyre renuncia, alegando: "impossível, com esses bobalhões em atividade". Assim, Estácio Coimbra vê-se diante de uma única solução: a de "trazer do Rio, para essa superior direção da Reforma, o próprio reformador, isto é, Carneiro Leão, continuando os Escobar a trabalhar com ele" (FREYRE, 2006, p. 296).

De volta a São Paulo, em janeiro de 1931, José Scaramelli retoma seu cargo de diretor no Grupo Escolar de Santo Antônio da Alegria. Aposenta no ano 1938, revertendo à atividade em 1945, quando, então, é nomeado para o cargo de professor de educação na Escola Normal Livre Imaculada Conceição, em Mogi Mirim. Em 1949, é removido por concurso para a Escola Normal Oficial de Rio Claro, onde exercerá a função de professor de Pedagogia e História da Educação. No mesmo ano, é declarado à disposição do Departamento de Educação, onde presta serviços até a data de seu falecimento, em 1955 (MELO, 1954; BRASIL, 1960; CAMARGO, 2000; SILVA, 2013). A biografia do autor, inscrita no projeto de Lei n. 281/1960 que deu origem à escola com seu nome na cidade de Guarulhos, onde foi sepultado, revela que José Scaramelli foi "apreciado e elogiado na Europa pelo emérito educador Adolphe Fèrrier, da Suíça, e por outros educadores como o professor Sud Menucci” (BRASIL, 1960, p. 13).

\section{O desvelar da essência e a razão para a adoção de uma escola nova brasileira}

Sob a influência do espírito científico, moderno e inovador da Escola Nova, cujos pressupostos são incorporados por meio da leitura atenta, da interpretação, da reflexão e do esforço de adaptação dos sistemas de pensamento de teóricos internacionais representantes desse movimento, José Scaramelli elabora o esboço desta nova orientação segundo necessidades do contexto educacional brasileiro. Sua iniciativa decorre da observação atenta das dificuldades de colegas que se dedicam ao ensino primário; das deficiências das escolas normais, onde ingressam professores sem concursos e cuja competência é uma incógnita; da mania de reformadores impenitentes, "que se revela até no prurido mórbido de mudar de nome aos cargos e as repartições" (SCARAMELLLI, 1931a, p. 8); da falta de assistência técnica organizada e do atraso pedagógico das escolas, que não permite o preparo conveniente para profissão a ser desempenhada. De acordo com José Scaramelli (1931a, p. 9), o atraso do meio em assuntos educativos, favoreceu o aparecimento de 


\begin{abstract}
"parvenus", com Ares de Doutor Sabetudo, Iluminados, Grandes Línguas, Fanfarrões mofados, que assumiram audaciosamente atitudes messiânicas e, acastelados em meia dúzia de revistas estrangeiras, com essa vaidadezinha pueril de mulherezinhas que se pintam aos domingos, puseram-se a ironizar, naturalmente sem as provas esmagadoras dos dados positivos, (não os traziam as revistas importadas), os professores que trabalhavam honestamente e que contribuíram com o seu esforço humilde, mas valioso, para o progresso do nosso ensino.
\end{abstract}

A audácia e o elogio mútuo - continua o autor - "levaram os iluminados às mais altas posições", destruindo muita coisa boa, construída pelos humildes. Com isso, "anarquizaram o que estava em ordem, perseguiram aqueles que não se deslumbraram diante do seu falso messianismo, nem se prosternaram em adoração perante a sua ciência importada, em fascículos, de além-mar" (SCARAMELLLI, 1931a, p. 9). Mesmo o professor mais obscuro, "que leva a sério a sua missão e que se esforça por ensinar, embora não empregue métodos ultramodernos, conseguirá resultados superiores aos dos iluminados, que clareiam apenas o caminho que conduz ao tesouro" (p. 10). Remetendo a um excerto do Manifesto da Legião Revolucionária de São Paulo, o autor destaca a ânsia em

combater esse patriotismo lírico e esse pessimismo que engendrou a grande calúnia da pequenez do brasileiro diante da terra. Esse homem raquítico é um desbravador de continentes, em luta perene contra todas as insídias de uma natureza hostil. Exaltar a sua grandeza e clamar pelos seus direitos é a obra de reparação e justiça da nova geração brasileira. Para isso precisamos impor uma mentalidade realista e ao mesmo tempo capaz de começar por afirmar-se a si própria, com feição, com diretriz, com energias próprias (SCARAMELLI, 1931a, p. 15).

Nos centros mais cultos do mundo, assinala o autor, a educação mantém-se na pauta dos grandes problemas sociais da atualidade. Não se trata de discussões sobre o melhor método de ensino ou o meio mais eficaz de plasmar as novas gerações para que promovam a grandeza das respectivas pátrias, mas de se expor e discutir, com dados positivos, após a observação e a experiência, os princípios da nossa educação. Neste processo deve-se prevalecer à ciência sobre seus procedimentos empíricos. "A educação que se manteve durante séculos, sobre a areia movediça do empirismo passa, em nossos dias, para o terreno sólido das ciências" (SCARAMELLLI, 1931a, p. 16). Os grandes movimentos que agitam o mundo culto, acrescenta, ressoam no Brasil conforme os casos e o estado de receptividade na ocasião. A Escola Nova não poderia fugir a regra. Os estadistas brasileiros preocuparam-se com o assunto e iniciativas oficiais esboçaram-se no Distrito Federal, em Minas Gerais, em Pernambuco e no Espírito Santo. Embora se anseie por uma Escola Nova perfeita, "que se articula com o meio imediato com a regularidade de uma revolução lunar e que funciona com a precisão de cronômetro", julgando ser capaz de se edificar "da noite para o dia, ao simples toque de vara mágica, [...] nosso atraso e a nossa inexperiência, não nos permitem abranger as questões do ensino de ângulo de sua complexidade verdadeira" (p.17). Assim seria muito cedo falar em resultados positivos. Mesmo em países mais desenvolvidos, incomparavelmente de mais ampla cultura que o Brasil, como Inglaterra, Estados Unidos, Suíça, Bélgica, França, Alemanha, Itália, entre outros, "ainda se fala, relativamente à Escola Nova, na 'fase de experiência' e nós aqui, sem ter começado ainda, já queríamos, como as crianças, os frutos, antes de plantar a semente ou quando muito durante a germinação" (p. 18). Entretanto, se é cedo para se falar 
em resultados positivos, não o seria para colher os frutos literários, pois a literatura da escola renovada é riquíssima no estrangeiro.

No Brasil, constata, apenas "copiamos, traduzimos e aproveitamos umas frases feitas para dourar pílulas que impingimos com... frutos literários da Escola Nova" (SCARAMELLI, 1931a, p. 18). Das iniciativas particulares de Escola Nova entre nós, considera a de Merity, nas proximidades do Rio de Janeiro, levada a efeito pela professora Amanda Álvaro Alberto, a única merecedora de registro. Em nossa prática cotidiana escolar, afirma, a metodologia renovada da instrução primária apresenta-se ainda sob a alcunha do "verbalismo inveterado que se apega a palavras" da prática docente (p. 56).

Há professoras que dizem ou descrevem as experiências, sem realizá-las: isto é um crime, que deveria ser registrado pelo código penal, cominandose apenas a quem o cometesse. [...] Já surpreendi, visitando um grupo escolar, uma professora que desenhava uma planta para ser "observada" pelos alunos. Entretanto no pátio de recreio desse grupo escolar dezenas de plantas vicejam soberbamente. Outra colega dava aula sobre insetos. Sobre as carteiras, diante das alunas, havia gafanhotos, baratas, formigas, barbeiros, grilos, abelhas, besouros, borboletas, em profusão. E não faltavam pinças, lentes, agulhas, álcool etc., isto é, bom material auxiliar. A professora ao invés de interessar as alunas na observação dos insetos naturais, mostrou-lhes um desenho colorido que representava um inseto esquematizado e, deu a aula pelo desenho, e explicou-me, gentilmente: É mais fácil, as meninas compreendem melhor (SCARAMELLI, 1931a, p. 55).

José Scaramelli (1931a, p. 55) destaca que, caso esse tipo de procedimento equivocado, esse "crime", fosse cometido por professor da Escola Normal, além da perda do cargo, este deveria ter, no mínimo, alguns meses de prisão celular. Pois,

da desídia e da má organização das escolas normais, decorrem todos os males do nosso ensino. E se a instrução é um dos maiores fatores da grandeza das nações, ninguém pode avaliar quanta culpa tem as escolas normais, nos males que afligem o país. Não é somente os maus políticos que levam a pátria à ruína, são também os maus professores.

Para o autor, "uma observação do natural vale mais que todos os desenhos esquemáticos do mundo. $\mathrm{O}$ desenho teria valor se fosse feito pela criança para sintetizar observações e experiências realizadas pela própria criança" (SCARAMELLI, 1931a, p. 56). Portanto, é indispensável que a escola seja um meio rico em sugestões, cujo ambiente deve ser provido de laboratórios (de Física, Química, História Natural e Higiene), farmácia de urgência, bibliotecas especializadas, horta, jardim, pomar, salas ambientes, museus, aquários, terrários, aviários, criação de pequenos animais (bicho da seda, abelhas, galinhas, patos, cobaias, lebres etc.), passatempos, jogos etc.; de modo que os alunos possam pesquisar à vontade. Afirma que, enquanto não houver tudo isso, ou quase tudo, não haverá escola nova. Haverá, senão, "macaqueações mais ou menos felizes, 'explicações ou descrições de experiências e desenhos esquemáticos de insetos"” (p. 57).

Essas escolas estarão para a escola nova como o animal empalhado está para o animal vivo, como o herbário seco está para a planta que ostenta ao sol a pompa de suas frondes. Nessas escolas não há vida, alegria, e felicidade para a criança. Há, apenas, o sobrecenho carregado, a ameaça 
constante, a lição cheia de mofo e de tédio de mestres que se bestializaram na rotina. $\mathrm{E}$ as crianças - seres de vida exuberante, que enchem os lares de alacridade, - sem terem cometido crime algum, são condenadas a passar diariamente várias horas nessas prisões torturantes, onde o espírito embrutece, à medida que a memória se entulha de coisas inúteis (SCARAMELLI, 1931a, p. 57).

Submetidos à tortura dos assuntos enfadonhos e intermináveis, que tornam seus interesses nulos, e das incansáveis preleções que se veem envolvidos ao longo de sua escolarização, José Scaramelli (1931c, p. 30) questiona o valor educativo transmitido por esta escola, uma vez que ela nada acrescentaria de novo ao seu patrimônio de conhecimentos e não enriqueceria sua experiência. A escola atual, afirma, tornou-se obsoleta, "envelheceu para os nossos dias, é a múmia com forma de escola que já não preenche, convenientemente, a sua finalidade". Já a Escola Nova, representaria a redenção da criança: "é sua alegria, o seu enlevo, a sua felicidade" (SCARAMELLI, 1931a, p. 58). Por isso, defende a imperiosa necessidade do abatimento destas "outras masmorras que prendem e estiolam, nos seus cubículos, as mais risonhas esperanças do Brasil"; anunciando a chegada da Escola Nova como a aurora dos tempos: "crianças de minha terra, um novo sol tinge com as mais belas cores o oriente da Pátria. Alegrai-vos: é a aurora da vossa redenção" (p. 59). Sua defesa funda-se no argumento de que esta orientação proporciona o desenvolvimento da socialização e integração da criança, que, iniciada no lar, amplia-se na escola e completa-se no seio da sociedade.

A socialização se fundamentaria na imitação social, constituída por quatro aspectos: o proveito imediato, o proveito mediato ou em benefício de outrem, os empreendimentos transitórios e o controle social. O autor explica que a Escola Nova, ao compreender a escola como comunidade ou a escola como cooperação, se organiza de modo que a criança tenha a oportunidade de imitar a sociedade em que se acha. $\mathrm{Na}$ sociedade, as pessoas que cercam a criança exercem atividades que lhes proporcionam o proveito imediato de seu sustento diário. O êxito dessas atividades, isto é, seu resultado depende da conjugação de esforços, da cooperação, em vista de um fim comum. A finalidade da comunhão de esforços consiste em proporcionar economia de tempo, de trabalho e de material em função da apresentação de um produto mais perfeito e barato. Como numa fábrica, os operários

trabalham visando um fim comum: a produção do objeto manufaturado, no prazo mais curto pelo menor preço. Numa alfaiataria, por exemplo, há um oficial-cortador que toma as medidas e corta os ternos. Um outro oficial que faz a paletó. Um terceiro que costura o colete. Um quarto que cose a calça. Enfim, um que passa a roupa e aprendizes que caseiam, rematam e pregam botões. Todos cooperam para a perfeição do produto e, como adquirem mais agilidade fazendo uma só peça, barateiam-no. $\mathrm{Na}$ fazenda de café, na de criação de gados, nos transportes, no armazém, etc. etc. é a mesma coisa: conjugação de esforços para um fim comum (SCARAMELLI, 1931a, p. 25).

Porém, como explica, se as atividades não se conjugam, não se ajustam, não se adaptam ou não se integram em um fim comum, mas se dispersam e se desintegram, o êxito cede lugar ao fracasso. Ao mesmo destino seriam conduzidas as crianças, quando não se ampliam convenientemente o seu grau de socialização no período escolar de forma que findada esta etapa de sua vida, possam integrar-se suavemente no meio social que a cerca. Mais tarde, carecerão fazê-lo em condições menos favoráveis, com perda de tempo, maior 
gasto de energias e sacrifícios econômicos evidentes. Ao socializar a criança, a escola economiza em benefício da sociedade: tempo, trabalho e dinheiro. Da mesma forma que na sociedade, na Escola Nova todos os alunos cooperam para um fim comum: o progresso da sala.

\begin{abstract}
Não há lições que cada criança estude ou memorize e recite à professora, que cada um aprenda para si e não se interesse pelos outros. Nas lições da Escola Nova, coopera a classe toda. No aprendizado da História, por exemplo, há alunos que trazem gravuras para fazer álbuns e cartazes, há quem forneça documentos, realize excursões, consulte autores, outros farão desenhos, redigirão trechos, farão sinopses, etc.. A primeira forma de imitação social é a do proveito imediato. A classe coopera para lição (SCARAMELLI, 1931a, p. 26).
\end{abstract}

A segunda forma de imitação social é apontada por José Scaramelli (1931a) como proveito mediato ou em benefício de outrem. É a associação de homens para o exercício de atividades não relacionadas com o proveito imediato de seu sustento diário. Da mesma forma que os homens se reúnem em sociedades religiosas, políticas, esportivas, beneficentes, dramáticas etc., os alunos também formam sociedades congêneres na Escola Nova. A terceira forma de imitação social constitui-se em empreendimentos transitórios. Como os adultos que se agrupam para realizar um empreendimento comum - festas, fazer uma recepção, organizar uma caravana etc. -, os pequenos da Escola Nova se agrupam para fins semelhantes e se distribuem em pequenas turmas para constituírem comissões parciais. A quarta forma de imitação social consiste no controle social, pois, da mesma forma que as atividades sociais são controladas por autoridades e funcionários,

a polícia controla a ordem e os bons costumes, a guarda-civil controla o tráfego urbano, o diretor da biblioteca pública controla a atividade dos consultantes, os sacerdotes controlam as atividades religiosas etc., também na Escola Nova há encarregados da disciplina, da biblioteca, das salas-ambientes, dos trabalhos manuais etc. (SCARAMELLI, 1931a, p. 28).

Quanto à integração, José Scaramelli (1931a, p. 29) esclarece que a Escola Nova socializa a criança, integrando-a no meio em que vive. As disciplinas são estudadas no meio e em função deste.

A escola articula-se com o meio imediato. Em excursões, quando acompanhadas pela professora, e livremente, nas horas não consagradas às aulas, as crianças exercem suas atividades no meio social que as cerca. Os problemas orientam as pesquisas na vida prática. A geografia, a história natural, a História da Pátria, a física, a química, a higiene, estudam-se no meio e em função do meio.

Compreendendo que "a escola não é uma preparação para a vida", mas "é a própria vida" (SCARAMELLI, 1931a, p. 34), o ensino da Escola Nova baseia-se nos interesses espontâneos das crianças. Nele, a professora não se vê diante dos alunos, mas "vê-se no meio deles. Não impõe regras, procura interessar as crianças. Não dá lições, guia, orienta, sistematiza a atividade interessada" (SCARAMELLI, 1931a, p. 35).

O interesse do aluno, aspecto orientador do ensino e da elaboração das lições, é um tema cuidadosamente abordado pelo autor, que se esmera no esclarecimento deste preceito, 
a fim de eliminar toda e qualquer dúvida que venha confundir o público alvo de sua obra: os professores. Em virtude das inúmeras colocações destes profissionais sobre como identificar o interesse do aluno, José Scaramelli (1931b, p. 8) explica que este deve ser tomado no sentido do adulto e não no da criança.

Um adulto, que já possui um certo patrimônio de conhecimentos e de experiências interessa-se por um aspecto determinado da realidade. $\mathrm{Na}$ criança - no imaturo - o interesse está, digamos assim, num estado de tensão, sempre ponto a deflagrar na direção de qualquer aspecto da realidade. [...] $\mathrm{O}$ aluno, interessado por um assunto, corre na direção que lhe é indicada pela professora. Esta, se conhece bem as crianças, sabe que aspectos são conhecidos pela classe, e serve destes para ponto de partida, afim de ir do conhecido para o desconhecido. Mas, guarda-se bem de anunciar como novidade aquilo que já é familiar aos pequenos. Em presença da novidade, do que não é conhecido, os adultos comportam-se como as crianças: interessam-se por qualquer aspecto da realidade. À medida, porém, que os aspectos se tornam conhecidos vão se acentuando as preferências, certos e determinados aspectos é que os interessam principalmente. Daí a possibilidade da lição.

O autor ressalta que, se o interesse for entendido a partir da ótica da criança, "cada criança deveria ter à sua disposição um exército de especialistas para educá-la" (SCARAMELLI, 1931b, p. 10). A direção do adulto é constantemente reiterada por José Scaramelli, que a compreende como instrumento para o desenvolvimento do espírito da verdadeira liberdade do indivíduo. Sobre esse aspecto, reserva parte de sua obra, para o que considera uma "verdadeira joia rara pedagógica": a tradução do artigo Independência, da renomada médica Maria Montessori, representante do movimento renovador educacional na Itália. Neste artigo, Maria Montessori afirma que não se pode ser livre sem ser independente e que as manifestações ativas da verdadeira liberdade devem ser dirigidas, desde a primeira infância, para a conquista da independência. Convencida de que esta concepção ainda não foi bem assimilada pelos educadores que, inseridos em relações sociais de servilismo, compreendem a ímpeto por servir como um ato de cortesia, amabilidade ou bondade, Montessori explicita o significado do termo independência, norteador da educação renovada, afirmando que "ao contrário do que julgamos, aquele que é servido é lesado em sua independência" (p. 76), pois se torna incapaz. O servilismo e a dependência impedem a criança, em sua educação, de se tornar autônoma e independente, uma vez que estes sufocam os movimentos espontâneos e úteis. Uma ação pedagógica sobre a criança, para ser eficaz, deverá ser dirigida, em primeiro lugar, para ajudá-la a seguir a caminho da independência. Desse modo, o dever daqueles que a educam consiste em ajudá-las a conquistar rapidamente os atos úteis, sem exceção.

A mãe que põe o alimento na boca do filho, sem fazer o menor esforço para lhe ensinar a segurar a colher e a procurar a boca, ou que não o faz observar os movimentos que ela realiza quando come, não é uma boa mãe. Ofende a dignidade de seu filho porque o considera um títere, quando, ao contrário, é um homem que foi confiado aos seus cuidados. Quem não compreende que ensinar um menino a comer, a lavar-se, a vestir-se é um trabalho muito maior, mais difícil e exige maior dose de paciência, do que realizar, por ele, estas diversas ações? (MONTESSORI apud Scaramelli, 1931c, p. 77). 
O primeiro trabalho - assegura Montessori - cabe ao educador, enquanto o segundo não é, senão, o trabalho inferior do criado: "trabalho não somente inferior e fácil, mas perigoso, que põe obstáculos à vida que se desenvolve, e que, além das consequências imediatas, pode ter as mais graves consequências futuras" (MONTESSORI apud SCARAMELLI, 1931c, p. 78). Aquele que se habitua a ser servido, além de tornar-se dependente, vê seus músculos se enfraquecerem na atividade e perderem a capacidade natural da ação. Sua própria mentalidade se atrofia e se desfalece.

O perigo do servilhismo e da dependência não está somente na usura inútil da vida, que conduz a incapacidade. Está também no desenvolvimento de reações que significam perversão e incapacidade. [...] A insolência se desenvolve paralelamente a incapacidade (MONTESSORI apud SCARAMELLI, 1931c, p. 80).

No entanto, a autora destaca que, "o homem que faz tudo o que pode, pessoalmente, dobra suas forças sobre as próprias ações, conquista-se a si mesmo, multiplica o seu poder e aperfeiçoa-se". Por isso, "cumpre fazer, para o futuro, gerações de homens poderosos, capazes, isto é, independentes e livres" (MONTESSORI apud SCARAMELLI, 1931c, p.81), que conduzam o destino futuro de sua Pátria. Dando seguimento a esta linha de pensamento, José Scaramelli (1931c, p. 30), ressalta a inadequação da Escola Tradicional e a fecundidade da Escola Nova que se mostra, evocando com urgência uma reforma "fond en comble" da educação. Alega que, para o progresso do país, acima de tudo, está "o preparo eficiente da mocidade estudiosa que dirigirá, amanhã, os destinos da pátria" (Grifos do autor).

A transição da pedagogia tradicional para a pedagogia renovada, segundo afirma, pode ser realizada "suavemente, sem aparelhagem custosa e sem grandes despesas" (SCARAMELLI, 1931c, p. 7). Pode ser iniciada sem delongas, com a simples orientação de seus opúsculos, bastando apenas boa vontade para se começar a trabalhar sob esta orientação. Não há a necessidade de se adquirir uma ideia ou conceito perfeito de Escola Nova, pois a experiência proporciona pontos de vista novos, novas visões panorâmicas do assunto, além de sugerir soluções, que darão margem para estudos mais apurados, novas pesquisas etc... Basta que se anime o espírito renovador para que as escolas transformemse radicalmente numa escola renovada. A Escola Nova, como explica, não nasceu pronta e armada para o combate, como Minerva da cabeça de Júpiter. Muito menos é capaz de fender o crânio do primeiro Júpiter de papelão que apareça. É uma conquista, que se faz paulatinamente, "estudando e experimentando com o ânimo disposto a acertar [...] é dinâmica, não se cristaliza e, por isso, não admite práticas rotineiras" (SCARAMELLI, 1931c, p. 9).

A Escola Nova não é alguma coisa fixa, imutável. É, pelo contrário, dinâmica, variável, em contínuo progresso. Somente praticando-a em larga escala poderemos bem compreendê-la e contribuir para aperfeiçoála. Apresentar um sistema complexo é desserviço prestado ao ensino. Ninguém o conheceria a não ser por um esforço inaudito de imaginação. A experiência é a grande mestra da vida e, com tanto maior razão, na Escola Nova (SCARAMELLI, 1931b, p. 10).

Todavia, embora a Escola Nova mostre-se mais interessante que a antiga, José Scaramelli esclarece que ela, ainda, enfrenta grande resistência em certos círculos, emergindo como o "terror sagrado que têm certos indivíduos supersticiosos pelas almas do 
outro mundo" (SCARAMELLI, 1931a, p. 9). Mesmo com as vantagens que propicia, objeções "mastodônticas" relativas à questão financeira acusam a inviabilidade de sua construção e instalação. Em tais discursos alegam-se que os novos métodos de ensino exigiriam dos governos o investimento de somas fabulosas com instalações e material consumível, para que as escolas preenchessem convenientemente a nova finalidade que lhes é determinada pela corrente filosófica de nossos dias.

É a objeção máxima - a questão monetária faz emudecer todas as bocas, esmaga todos os argumentos, atravanca todos os caminhos. É a muralha chinesa que se antepõe à caudal que avança. Mas, os que escancaram assim a boca e arregalam tão desmedidamente os olhos, onde viram escolas novas? Onde obtiveram dados econômicos positivos? Por que não argumentaram com cifras? (SCARAMELLI, 1931c, p. 21).

Estas críticas, de acordo com o autor, não se fundam em dados realísticos que comprovam o custo efetivo e a viabilidade das instalações da Escola Nova. Ao comparar o custo para as construções e as instalações relativas à Escola Tradicional e à Escola Nova, aponta o alto investimento empregado pela primeira.

Em S. Paulo, por exemplo, construíram-se prédios suntuosos, caríssimos para as escolas urbanas como se, nas cidades paulistas, o ensino não se pudesse realizar senão no meio de pompas e magnificências. Enquanto gastavam quantias soberbas em mobiliários custosos, alegava-se que, por medida de economia, não se podiam instalar pequenos laboratórios escolares, que poderiam custar poucas centenas de mil réis cada um. Gastava-se fartamente para o supérfluo e achavam-se desculpas para não comprar o necessário. Os grandes prédios que ostentam fachadas de centenas de metros já fizeram época. Hoje em dia serão excelentes pour épater les bourgeois e para dar aos entendidos uma prova arqueológica do nosso atraso pedagógico (SCARAMELLI, 1931c, p. 22).

Entretanto, assegura que, a metodologia renovada - com excursões a pé nas proximidades da escola, realização de experimentos simples e investigações práticas, para a solução de problemas imediatos e da vida real etc. - não traz despesas à escola.

Com pequenos gastos, com iniciativa e boa vontade, quer dos alunos, quer dos professores, organizam-se, pouco a pouco, pequenos museus, salas ambientes, pequenos laboratórios, etc., etc., e vai-se caminhando em direção do ideal sonhado (SCARAMELLI, 1931c, p. 8).

A construção de escolas adaptadas à sua metodologia - certifica José Scaramelli (1931c, p. 23) - oferece redução de custo.

Salas modestas - a palavra pavilhão dá a impressão de suntuosidade construídas em terrenos amplos, distantes dezenas de metros umas das outras, entre jardins, pomares e hortas, plantados pelas próprias crianças, naturalmente guiadas por técnicos experimentados, é que devem ser as escolas modernas. Ao invés de um grupo escolar de 150 a 200 contos, por que não fazer apenas 4 ou 6 salas, no meio de um terreno murado? E por que não construí-la de forma que seja fácil, quando necessário, sobreporlhe um andar? Seria bem mais simples, mais barato e mais moderno. As economias, que se fizerem desta forma, permitiriam a instalação de 
pequenos laboratórios e outras despesas necessárias, que estão longe de fabulosas.

Quanto às vantagens econômicas oferecidas pela Escola Nova em relação ao seu material e mobiliário, facilmente adaptado às necessidades de sua filosofia, destaca:

Em lugar de carteiras de ouvir lições, como as chamou um fabricante interpelado por Dewey, por que não usar mesinhas de trabalho que podem custar $12 \$$ e $15 \$ 000$ ? Por que não substituir os bancos pelas cadeiras, mais econômicas e mais práticas? Uma mesinha e uma cadeira custarão de $20 \$$ a $25 \$ 000$ ao passo que as carteiras, verdadeiros anacronismos pedagógicos, custam duas ou três vezes mais. E pode haver tipos ainda mais econômicos: uma mesa e seis cadeiras para cada equipe. Com seis mesas e três dúzias de cadeiras está mobiliada uma classe. Mas... - lá vem a objeção mastodôntica, - as mesas não tem plano inclinado para a leitura e escrita. - Que dificuldade absurda! Com poucos mil réis mandam-se fazer planos inclinados que se adaptem às mesas, nas ocasiões oportunas e, se a objeção é cabível, era uma vez... (SCARAMELLI, 1931c, p.23).

Justificada a viabilidade econômica da implantação da escola nova, José Scaramelli (1931c, p. 15) detém-se na análise dos aspectos didático-metodológicos do ensino da Escola Tradicional e da Escola Nova. Explica que, na escola tradicional, "tomando-se a expressão em sentido pejorativo", ministrava-se, geralmente, à criança, a "ciência feita".

Nada de pesquisa, nenhum esforço para conquistar a ciência. A investigação era termo desconhecido, a iniciativa do aluno, quebra de disciplina. $\mathrm{O}$ essencial era que os imaturos gravassem, na memória, umas tantas informações... e a missão da escola no tocante aos conhecimentos indispensáveis a todo indivíduo de determinada sociedade, estava realizada. A didática reduzia-se a uma mnemônica. O professor mais esperto era o que descobria ou catalogava maior número de "regrinhas" mnemônicas: meros expedientes para gravar melhor a ciência feita. A observação e a experiência eram empecilhos que dificultavam o ensino. Por que devia a criança trabalhar dias e dias para descobrir qualquer coisa, se a professora em poucos minutos lhe dizia tudo? Por que tanto esforço, se o resultado era tão fácil de alcançar? Por que realizar experiências, se a professora "explicava" em meia dúzia de palavras, como se fazia e que fenômeno seria observado? Era ilusão - que tanta gente alimenta em nossos dias - de que o saber se transplantava do cérebro do professor para a cabeça do aluno, da página do livro para a inteligência da criança. [...] Assim, como dois pontos determinam a posição de uma reta, duas palavras definem a escola tradicional: explicarmemorizar. Explicar era a função do professor. Memorizar, a tarefa que incumbia ao aluno.

Para ilustrar a prática docente corrente, oferece como exemplo as experiências vivenciadas enquanto diretor de escolas, revelando um professorado ainda muito apegado às convenções e metodologias que denomina de tradicionais e antigas.

E professores havia que, não só não permitiam aos alunos a liberdade de opinião, como também não lhe concediam a forma de expressá-la: a lição 
devia ser repetida opsis litteris, sem discrepâncias. [...] Aí está como se matavam, no nascedouro, as personalidades que desabrochavam para a vida e para a glória (SCARAMELLI, 1931c, p. 16-17).

José Scaramelli (1931c, p. 67) assegura que não falta boa vontade, nem competência ao nosso professorado para prover a implantação do ensino renovado, mas, faltam aos Estados, os técnicos capazes de orientá-los convenientemente.

Repitamo-lo: faltam os técnicos que se dediquem a esses estudos especializados e que tenham o santo estoicismo, a sublime renuncia, de ficar na sombra, a fim de que os "predestinados" da cultura geral e superficial deslumbrem, como sóis coruscantes, a multidão ignara, que aplaudem sempre, delirantemente, todos os messias de... marionetes e crucifica os verdadeiros apóstolos.

A Escola Nova, para ele, somente será uma risonha realidade no ensino primário brasileiro, quando a formação do magistério, em sua integralidade, fundar-se em seus preceitos: "a Escola Nova será uma risonha realidade quando o magistério, na sua totalidade, se constituir de professores que se tenham educado nela. Antes dessa data continuaremos, provavelmente, no terreno experimental" (SCARAMELLI, 1931a, p. 18).

Ciente das singularidades e das limitações do contexto educacional brasileiro, preocupado em desvelar os princípios erigidos em relação à Educação Nova, elucidando, em uma linguagem de fácil entendimento e em demonstrações de cunho prático, as vantagens e contribuições que este ensino proporciona à infância brasileira, José Scaramelli dedica-se a construir um esboço do sistema escolanovista voltado à realidade de seu país. Em seu esforço, confessa que, galgando tímidos passos para propiciar a Escola Nova Brasileira, procura evitar os erros de seus contemporâneos que propagam uma suposta pedagogia renovada por meio de cópias, traduções e frases feitas. Afirma que os sistemas educativos não se transplantam e que a Escola Nova Brasileira que propõe, fundase não em cópias e traduções de autores, mas na assimilação da essência desta filosofia, que pudesse contribuir e servir à realidade de nossas escolas.

Para as linhas gerais do sistema [...] não copiei, nem traduzi autores. Li as obras de Dewey, Decroly, Ferrière, Lombardo-Radice, Demolins e tantos outros. Os seus ensaios práticos não me fascinaram. Interessou-me vivamente a essência da doutrina, que procurei assimilar na medida que me era possível. Habituado a pensar com a minha cabeça, não sei rezar pelas cartilhas alheias. Por isso não me preocupei em ser fiel aos Mestres, quer na doutrina, quer na prática. Se há neste opúsculo, pontos de contato com as teorias dos autores mais em voga, no momento incerto que passa, é porque, em muitos casos, eles têm-me servido como ponto de referência. Nada mais (SCARAMELLI, 1931a, p. 7).

A disseminação dos preceitos escolanovistas, segundo considera, consiste em uma melhor compreensão e debate para o aperfeiçoamento e adequação do processo de ensino da infância brasileira. Eis, então, que se dedica a deslindá-los, oferecendo um esboço didático-metodológico para a realidade de nossas escolas.

\section{Pilares para uma escola nova brasileira}


Diante da tarefa de elucidação e disseminação dos preceitos escolanovistas entre o magistério brasileiro, exaltando a superioridade de seu ensino frente aos modelos vigentes, José Scaramelli atribui ao estudo da didática o papel essencial da prática docente, da qual deriva a metodologia capaz de promover o ensino adequado às necessidades da sociedade moderna. De acordo com o autor, a maioria dos fracassos do ensino tem suas raízes na deficiência da didática, pois sem uma base sólida, o professor não poderá cumprir sua missão. Afirma que, "onde escasseia a técnica, a eficiência é falha e somente uma dedicação fora do comum poderá supri-la" (SCARAMELLI, 1931d, p. 8).

No que diz respeito à didática, José Scaramelli esclarece que, seu estudo demanda a compreensão sobre: a origem e essência do conhecimento, como se aprende, a função do conhecimento e da estruturação dos princípios norteadores do trabalho docente. A origem do conhecimento, segundo o autor, baseia-se na relação estabelecida entre os aspectos biológicos e psicológicos do indivíduo, manifestando-se como uma condição de equilíbrio e adaptação constante deste em relação ao seu meio. A atividade psicológica se manifesta como uma condição nova de adaptação, necessária aos organismos quando atingem certo grau de complexidade. Sua atividade está subordinada à evolução e ao funcionamento de um determinado ser em um determinado meio, estabelecendo um contato mais estreito e um equilíbrio mais perfeito entre o organismo e o meio. A atividade psicológica (indícios da consciência) origina-se a partir das primeiras sensações provocadas pelas excitações do meio. As primeiras noções são constituídas pelo sentimento vago de um movimento e a apreciação de seus resultados, que aos poucos se afinam, tornando-se mais elaborados por meio de uma seleção rigorosa das sensações vivenciadas e resultando na distinção de diferentes reações e precisão de seus efeitos. A espontaneidade dá lugar à reflexão, subordinando a vida afetiva à intelectual, proporcionadora de noções mais precisas, seguras, úteis e práticas. Despontam-se a vida representativa, o conhecimento e a representação dos objetos exteriores e de si mesmo.

A essência do conhecimento (o que é o conhecimento?), segundo José Scaramelli (1931d), está relacionada à conexão estabelecida entre a atividade mental (psicológica) e o sistema nervoso (atividade biológica). $\mathrm{O}$ cérebro, além de funcionar como um mecanismo especializado em manter a colaboração conjunta de todas as atividades corporais orgânicas, também se comporta como um órgão de coordenação da resposta motora, efetuando o ajustamento recíproco dos estímulos recebidos do meio e da resposta adequada. Ao mesmo tempo, que o cérebro proporciona a atividade orgânica para reagir sobre um objeto em resposta à estimulação sensível, esta resposta determina e modela o estímulo seguinte. Isto faz dele um mecanismo destinado a uma constante reelaboração e reorganização da atividade, na qual recolhe a matéria da experiência anterior, percebendo-a como matéria de uma nova experiência, de modo a manter-lhe a continuidade. De acordo com o autor, o conhecimento deve ser entendido, não como algo completo em si, isolado e descontínuo, mas em conexão a outros acontecimentos e respondendo às suas conexões. Somente podese chamar de conhecimento "o que se organizou em nossa disposição e nos dá capacidade para adaptar o meio às nossas necessidades e adaptar nossas necessidades e desejos à situação em que vivemos". O conhecimento não é algo de que temos consciência, consiste na "disposição que utilizamos conscientemente para compreender o que agora ocorre [...] com o fim de fortalecer uma perplexidade, concebendo a conexão entre nós e o mundo em que vivemos" (DEWEY apud SCARAMELLI, 1931d, p. 65).

A função do conhecimento, conforme explica José Scaramelli (1931d, p. 95), “é a de refazer e reorganizar a nossa experiência. Novo conhecimento é nova experiência. Cada experiência nova reconstrói e reorganiza a experiência anterior, isto é, educa". Diferente do hábito, que torna uma experiência mais fácil e eficaz para outras análogas no futuro, 
sem, no entanto, dar margem à mudança de condições (às novidades), em virtude de sua tarefa supor a semelhança essencial da nova situação com a antiga, a função do conhecimento consiste em uma percepção das conexões da aplicabilidade de um objeto em uma dada situação e na capacidade de antecipar as consequências futuras, introduzindo na ação futura as modificações requeridas pelo que já foi feito.

$\mathrm{O}$ aspecto da didática que trata de como se aprende é compreendido mediante a aquisição de um comportamento modificado, no qual o autor encontra solução na teoria do reflexo condicionado de Pavlov - por meio de um estímulo externo se produz um dado comportamento -, na lei da recorrência - manutenção do comportamento adquirido sem indução por estímulo - e no trabalho de Dewey sobre interesse transferido - o indivíduo participa da significação social da atividade. Com base nas formulações de Dewey, José Scaramelli explica que conhecimentos indiferentes ou mesmo repulsivos tornam-se interessantes mediante o estabelecimento de relações e ligações, fazendo nascer a consciência da importância destes meios para se levar adiante e efetivar uma atividade.

A aproximação entre as teorias de Pavlov e Dewey, realizada pelo autor, é justificada pelo fato de a primeira possibilitar a explicação da aquisição de um comportamento modificado (como se aprende) e a segunda propiciar meios para orientar e dirigir esse processo, suscitando o interesse da criança por meio do desenvolvimento contínuo e duradouro de uma atividade, na qual possa "associar-se a experiência comum, modificando de acordo com ela seu estímulo interno, e sentindo, como próprio, o êxito ou o fracasso da atividade" (SCARAMELLI, 1931d, p. 84). José Scaramelli (1931d, p. 62) assegura que nada há que proporcione aos discípulos o conhecimento, a não ser "o que aprendem, encontrando-o na experiência e em função da experiência".

Fundamentado em tais concepções, José Scaramelli (1931d, p. 98) explica que as condições para o adequado desenvolvimento educativo demandam a cooperação harmônica dos três fatores: a estrutura nativa de nossos órgãos corporais e suas atividades funcionais, o uso a que se consagram as atividades desses órgãos sob o influxo das demais pessoas e sua interação direta com o ambiente. Compreende que, embora as atividades nativas dos órgãos constituam a base desta cooperação, servindo de ponto de partida para o aprendizado, o desenvolvimento dos órgãos e das faculdades nativas não ocorre espontaneamente, mas mediante o uso e a direção dados pelo adulto. Assegura que não há atividade educativa, ou seja, reorganização consciente da experiência, sem que haja direção, governo, controle. A missão do meio social, ou seja, da tarefa educativa, consiste em "proporcionar à criança o que não lhe concedeu a natureza, isto é, o hábito do controle social, a subordinação dos poderes naturais às regras sociais". Quanto à interação direta com o ambiente, esta proporciona a cultura, uma experiência mais rica e um ponto de vista mais amplo. Portanto, o processo educativo é um processo de interação e ajustamento entre a criança e a experiência do adulto.

O programa escolar deve, portanto, considerar os dois elementos fundamentais do processo educativo: a criança - considerada como um ser imaturo, não evoluído - e certos fins, ideias e valores sociais representados pela experiência amadurecida do adulto. A adequada interação entre esses elementos engendrará o processo educativo. Trata-se, pois, de "obter uma reconstrução que parta da experiência infantil atual para a experiência representada pelos corpos organizados de verdades, a que chamamos "matérias de estudo"" (SCARAMELLI, 1931d, p. 103). As verdades e os fatos que compõem tanto a experiência atual da criança como a matéria de estudo constituem os termos, inicial e final, de uma só realidade. "Opor um ao outro, é opor a infância contra a madureza de uma mesma vida; é contrapor o impulso para crescer ao resultado final do crescimento; é dizer que a natureza e o destino se guerreiam na criança" (SCARAMELLI, 1931d, p. 104). As matérias de estudo 
têm, portanto, a função de interpretar a natureza infantil. Sua utilização, no sentido de dirigir e guiar a educação, é uma expansão desse pensamento.

Nesta perspectiva, o método de ensino (metodologia) não é exterior ao material, mas consiste na combinação e direção deste, tornando-o mais eficaz ao uso e em conformidade com os resultados desejados.

Em resumo: $\mathrm{O}$ método não é uma fórmula que indica como se deve "arranjar" o material para que se grave melhor no espírito do que aprende; nem é também um conjunto de "regrinhas mnemônicas" para facilitar a aquisição e a posse do material. Método é uma relação de conveniência entre o discípulo (necessidade sentida) e a matéria que deve ser ensinada (fim em vista). Em outras palavras, o problema é o de descobrir a relação intrínseca entre a matéria ou o objeto, e a pessoa. Essa relação passará a ser motivo de atenção quando conscientemente percebida (SCARAMELLI, 1931d, p. 88. Grifos do autor).

A efetivação desse método de ensino, segundo o autor, pode ser contemplada mediante a implementação das lições ativas. Seu desenvolvimento ocorre mediante a experiência de uma situação de vida (situação total), da qual decorre uma necessidade (problema) a ser resolvida pelo educando, que se envolve e participa ativamente de todo o processo de investigação, análise e inferência dos resultados, por meio de trabalhos em grupos e individuais, discussões em assembleias, experimentos, observações dos fenômenos, pesquisas, excursões, organização e síntese do material etc.. Nesse processo, o professor faz da escola, não somente uma preparação para a vida, mas a própria vida. Suscita o interesse do aluno, compreendido a partir da ótica do adulto; promove os centros de interesse; o método de pesquisa; o autoensino e a globalização, de modo a ampliar conhecimentos e desenvolver autonomia nos alunos e ainda, para que não haja a especialização destes em um só assunto e atividade, interpreta o crescimento infantil a fim de conciliá-lo e adequá-lo ao programa escolar, prevê o fim de cada atividade e provê constantemente a orientação e a direção da educação. As lições ativas e os princípios estruturantes da pedagogia nova refletem-se no conjunto da obra didático-literária do autor, voltada para a abordagem de conteúdos do programa escolar para a instrução da infância brasileira e a instrumentalização da atividade docente.

Apesar de sua condição de arte nascente, não consolidada no terreno da ciência, os testes mentais, de acordo com José Scaramelli (1931e), constituem outro recurso capaz de conferir uma significativa contribuição ao processo de ensino, prestando bons serviços ao professor. No Brasil, conforme explica, embora estudos tenham sido feitos em relação à escala Binet-Simon, ainda não houve uma revisão e adaptação desta ao nosso contexto, sendo utilizada a tradução de obras de autores, como a realizada por Lourenço Filho. Apesar da contribuição prestada, adverte que os testes mentais não devem ser considerados infalíveis e tratados com fanatismo. Concebida a partir do pressuposto de que o homem é feliz e a sociedade está bem organizada quando cada indivíduo se dedica às atividades para as quais está naturalmente dotado. A função da educação consiste, portanto, em "descobrir esses dotes aos olhos do mesmo indivíduo que os possui, e treiná-lo para sua utilização eficaz". Em função de os testes mentais permitirem, "hodiernamente, descobrir os dotes do indivíduo, senão na totalidade, pelo menos em parte apreciável e já ponderável" (SCARAMELLI, 1931d, p. 124), estes podem ser aproveitados como um meio de conhecer melhor os nossos alunos (física, intelectual e moralmente), verificar o êxito ou o fracasso do ensino, organizar as classes com mais cuidado, etc.. 
Com base nos trabalhos de Durkheim, Kilpatrick, Dewey, Ferrière, Binet, Claparèd entre outros, elabora um decálogo a fim de sintetizar o quinto aspecto de que trata a didática, princípios norteadores que devem reger o trabalho docente. Eis os preceitos: $o$ interesse do aluno - compreendido como a "necessidade de saber ou agir". Por não existir naturalmente, é necessário criá-lo, estimulando-o de modo extrínseco e o intrínseco - , $o$ conhecimento -compreende somente aquilo que se "organizou em nossa disposição e nos capacita a adaptar o meio às nossas necessidades e adaptar nossas necessidades e desejos à situação em que vivemos" (DEWEY apud SCARAMELLI, 1931d, p. 117) -, $a$ socialização da criança, o trabalho em comunidade - fundamentado na obra de Durkheim, concebe a educação como instrumento para perpetuar e reforçar a homogeneidade, fixando de antemão, na alma da criança similitudes essenciais, reclamadas pela vida coletiva, preparando a criança às condições essenciais da própria existência. Admitido o princípio da socialização, José Scaramelli (1931d, p. 121) explica que também se aceitarão todas as consequências que dele decorrerão: "autonomia dos escolares (Ferriére) socialização para a democracia, eficácia social (Dewey), prática normal da própria vida (Kilpatrick), articulação da escola com o meio imediato, associações de pais e mestres, jogos educativos etc.". -, a globalização - fundado na "coesão entre as diversas atividades da criança", obedece a uma lei de interesse: "qualquer coisa indiferente ou desagradável torna-se interessante quando vista como um meio para conseguir um fim que já nos atraiu a atenção" (p. 122) -, os atos com um fim em vista ou atos com um fim previsto - é aquele que, segundo o autor, "identifica o processo da educação com a própria vida" (p. 123) -, a verificação objetiva pelos testes - tomando como premissa o pensamento de Platão, que afirma que o homem é feliz e a sociedade está bem organizada, quando cada indivíduo se dedica às atividades para as quais está naturalmente dotado, assegura que a função da educação consiste, pois, em "descobrir esses dotes aos olhos do mesmo indivíduo que os possui, e treiná-lo para sua utilização eficaz". Alfred Binet abriu caminho para a realização do sonho do pensador grego: "são os testes que permitem, hodiernamente, descobrir os dotes do indivíduo, senão na totalidade, pelo menos em parte apreciável e já ponderável para nos irmos aproximando do ideal do filosofo citado" (p. 124) -, a educação moral $e$ cívica - com base na concepção de escola como uma sociedade em miniatura, afirma que a educação deve ser concebida como meio para o desenvolvimento da capacidade de participar eficazmente da vida social - a educação física - fundamentado em Emerson, reiterado por Spencer, a afirmação de que a primeira condição para o êxito na vida é "ser um bom animal" (p. 125) -, educação econômica - capaz de engendrar no aluno noções de poupança (conservação e resguardo dos bens), de boa aplicação (uso conveniente dos bens, visando ao máximo rendimento, a partir do menor gasto de energia) e de equilíbrio orçamentário (gasto em conformidade com a renda e saldo favorável) - e educação estética - considerada como o elemento que permeia todos os trabalhos e áreas do conhecimento.

\section{Conclusão}

Sem o caráter de encerramento do assunto, mas de trazer contribuições para a discussão e compreensão da História da Educação pública brasileira, a proposição de uma Escola Nova Brasileira por José Scaramelli revela uma revisão crítica da problemática educacional, na qual a Escola Nova, colocada como antítese da Escola Tradicional, fundamenta uma nova concepção de criança - ser ativo, que se educa em sua interação com o ambiente - e infância - fase de formação e amadurecimento. Em consequência, a educação centra-se no processo de desenvolvimento natural da criança, desenvolvendo 
uma nova percepção da natureza da escolarização e do programa escolar, do processo de ensinar e aprender e do papel do educador. Este se torna um intermediário, que se volta para estreitamento e ampliação das relações do indivíduo com o meio, aproveitando e criando circunstâncias, para que o aluno se desenvolva naturalmente mediante a própria experiência, de modo que, no futuro, possa ser capaz de associar, abstrair, raciocinar e agir por conta própria. Devido à atividade educativa partir do interesse e necessidade da criança, questiona-se o programa escolar e o significado das matérias de estudos, alterando-se a compreensão de didática, que passa a demandar da experimentação de novos meios e, portanto, a revisão dos métodos pedagógicos, concebidos segundo o desenvolvimento das potencialidades da personalidade integral da criança. Os conteúdos escolares são selecionados, não por critérios exteriores, mas de acordo com as características do desenvolvimento natural do escolar.

Os aspectos psicológicos do conhecimento se sobrepõem aos aspectos lógicos. Surge um novo conceito de aprendizagem, baseada, não mais no imobilismo, mas na educação pela ação, levando a adoção da orientação da escola ativa e do "aprender fazendo". Em sua metodologia, o aluno ouvinte dá lugar ao aluno-pesquisador, que aprende em sua relação direta com o meio, com as coisas e com as pessoas, por meio dos processos de pesquisa, de investigação, da ação, da experimentação, das descobertas, da reflexão, de deduções. O ensino se estrutura segundo processos objetivos e práticos, permitindo o desenvolvimento da inteligência do aluno de maneira orientada e de padrões de comportamento. A partir da concepção de democracia social, em que a escola prepara para a vida, ou melhor, é a própria vida, institui-se a aprendizagem da vida coletiva e a realização da unidade nacional, derivando-se daí a função da escola de ensinar a viver em sociedade, para que os indivíduos, parte constitutiva da sociedade orgânica, contribuam para a elevação desta mediante o desenvolvimento do hábito de agir e trabalhar em cooperação, pois somente deste modo o país poderia alcançar a condição de progresso e desenvolvimento, semelhantes aos dos países mais desenvolvidos.

Diante das possibilidades oferecidas por seu espaço e tempo a proposição de uma Escola Nova com características brasileiras por José Scaramelli pode ser compreendida, como admite o próprio autor, como o "esboço" de um sistema didático-metodológico, que permite a propagação de suas ideias pedagógicas e de uma melhor compreensão e debate de seus princípios por parte do magistério nacional, a fim de promover seu aperfeiçoamento e adequação do processo de ensino da infância brasileira. Observa-se que o autor elabora seu esboço mediante a apropriação e reprodução de sistemas de pensamento dos precursores internacionais deste movimento, sugerindo um modelo pedagógico a partir de observações diretas e descrições de aulas práticas acumuladas ao longo da experiência da profissão, mas que, porém, são desprovidas de investigações e pesquisas complementares que permitam validar e, mesmo, refutar as proposições sugeridas em relação às peculiaridades e às necessidades da escola brasileira de seu período, engendrando conhecimentos teórico-práticos capazes de suplantar os modelos pedagógicos, então, estabelecidos e servir como solução efetiva aos problemas educacionais da instrução pública primária que conhece bem.

\section{Referências}

A REFORMA da educação em Pernambuco: dentre os estados que estão reformando o seu ensino é Pernambuco o que realiza reforma mais radical, diz o "Diário de S. Paulo". A 
Província, Recife, 27 fev. 1929, p. 3. Disponível em: <http://memoria.bn.br/pdf/128066/per128066_1929_00048.pdf>. Acesso em: $27 \mathrm{dez}$. 2012.

ARAÚJO, Cristina. A Escola Nova em Pernambuco: educação e modernidade. Recife: Prefeitura do Recife; Secretaria da Cultura; Fundação de Cultura, 1991.

BARBOSA, Ana Mae. John Dewey e o ensino da arte no Brasil. 2. ed. São Paulo: Cortez, 2011.

BRASIL. Decreto n. 20.778, de 12 de dezembro de 1931. Disponível em: <http://www6.senado.gov.br/legislacao/ListaTextoIntegral.action?id=21083>. Acesso: em 27 dez. 2012.

CAMARGO, Marilena Aparecida Jorge Guedes de. Coisas velhas: um percurso de investigação sobre cultura escolar (1928-1958). São Paulo: Ed. UNESP, 2000.

CARNEIRO LEÃO, Antonio. Justificativa. In: PERNAMBUCO. Organização do Estado de Pernambuco. Recife: Imprensa Oficial, 1928. p. 7 - 30.

O Brazil e a educação popular. Rio de Janeiro: Jornal do Commercio, 1918.

CARVALHO, Marta Maria Chagas. Reformas da instrução pública. In: 500 anos de educação no Brasil. 3. ed. Belo Horizonte: Autêntica, 2007. p. 225 - 251.

FREYRE, Gilberto. Tempo morto e outros tempos: trechos de um diário de adolescência e primeira mocidade (1915 - 1930). São Paulo: Global; Recife, PE: Fundação Gilberto Freyre, 2006.

INSTRUÇÃO Pública. Folha da Manhã, São Paulo, 13 abr. 1928, p. 11. Disponível em: <http://acervo.folha.com.br/fdm/1928/04/13/141/>. Acesso em: 6 fev. 2012.

LE GOFF, Jacques. A história do quotidiano. In: ARIÈS, P.; DUBY, G. \& LE GOFF, J. (Org.). História e nova história. 3. ed. Lisboa: Editorial Teorema, 1994. p. 85 - 96.

LEMOS FILHO. Clã de açúcar: Recife: 1911 - 1934. Rio de Janeiro: Livraria São José, 1960.

MELO, Luís Correia de. Dicionário de autores paulistas. São Paulo: Ed. Gráfica Irmãos Andrioli, 1954.

MONARCHA, Carlos. A Escola Normal da Praça: o lado noturno das luzes. Campinas: Ed. Unicamp, 1999.

. Notícia documental e bibliográfica sobre as "missões de professores paulistas". In: COSTA, Célio Juvenal; MELO, Joaquim José Pereira; FABIANO, Luiz Hermenegildo (Org.). Fontes e métodos em história da educação. Dourados, MS: UFGD, 2010. p. 243 -265 .

PROFESSORES paulistas vão reformar o ensino em Pernambuco: São Paulo continua a auxiliar a instrução em todo o país. Folha da Manhã, São Paulo, 25 jan. 1929, p. 2.

Disponível em: <http://acervo.folha.com.br/fdm/1929/01/25/141//4519399>. Acesso em: 6 fev. 2012.

ROCCO, Salvador (Org.). Bandeirismo. Centenário do ensino normal em São Paulo: 1846/1946. Polianteia comemorativa do ensino normal. São Paulo: Gráfica Brescia, 1946, p. $69-75$. 
SÃO PAULO (Estado). Assembleia Legislativa do Estado de São Paulo. Projeto de Lei 281/1960. Diário Oficial do Estado de São Paulo, São Paulo, 22 jul. 1960, p. 13.

Disponível em: <http://www.jusbrasil.com.br/diarios/5593067/dosp-suplemento-poderexecutivo-22-07-1960-pg-11/pdfView>. Acesso em: 6 fev. 2012.

. Secretaria do Interior. Diário Oficial do Estado de São Paulo, São Paulo, 18 maio 1919, n. 109, p. 3083. Disponível

em:<http://www.jusbrasil.com.br/diarios/3797951/dosp-diario-oficial-18-05-1919-pg3083/pdfView>. Acesso em: 6 fev. 2012.

SAVIANI, Demerval. História das ideias pedagógicas no Brasil. Campinas: Autores Associados, 2007a.

Instituições Escolares no Brasil: conceito e reconstrução histórica. In:

NASCIMENTO, Maria Isabel Moura et. al. (Org.). Instituições Escolares no Brasil: conceito e reconstrução histórica. Campinas: Autores Associados: HISTEDBR, Sorocaba: UNISO, 2007b, p. 03 - 32.

SCARAMELLI, José. Escola Nova Brasileira: esboço de um systema. São Paulo: Livraria Zenith, 1931a, v. 1.

Escola Nova Brasileira: lições Ativas. São Paulo: Livraria Zenith, 1931b, v. 2.

Escola Nova Brasileira: como realizar a transição da Escola Tradicional para a Escola Nova. São Paulo: Livraria Zenith, 1931c, v. 3.

Escola Nova Brasileira: didática. São Paulo: Livraria Zenith, 1931d, v. 4.

Escola Nova Brasileira: testes. São Paulo: Livraria Zenith, 1931e, v. 5.

SILVA, Débora Alfaro São Martinho da Silva. José Scaramelli: um bandeirante do ensino paulista na implementação e divulgação de uma didática e metodologia da educação nova para a infância brasileira. 2013. 225 f. Dissertação (Mestrado) - Centro de Educação e Ciências Humanas, Universidade Federal de São Carlos, São Carlos, 2013.

TOLEDO, João. Nossa gente: notas pedagógicas para meus alunos. Revista da Escola Normal de São Carlos, SP, ano 3, n. 5, p. 31 - 42, dez., 1918.

VAINFAS, Ronaldo. Micro-história: os protagonistas anônimos da história. Rio de Janeiro: Campus, 2002.

Notas

\footnotetext{
${ }^{1}$ Doutoranda em Educação na Universidade Federal de São Carlos (UFSCar).

${ }^{2}$ Pós-doutora em Filosofia e História da Educação pela Unicamp. Professora Adjunta da Universidade Federal de São Carlos (UFScar).
}

Recebido em setembro-13

Aprovado em novembro-13 